\title{
Error Analysis Using Newman Procedures and the Mathematical Representation Ability of Pre Service English Teachers
}

\section{Utut Kurniati}

Universitas Swadaya Gunung Jati, Indonesia, ututkurniati@fkip-unswagati.ac.id

Setiyani

Universitas Swadaya Gunung Jati, Indonesia, setiyani@fkip-unswagati.ac.id

Laela Sagita

Universitas PGRI Yogyakarta, Indonesia, laelasagita@upy.ac.id

This study aims to describe the representation ability profile of prospective English teachers in terms of Prior Knowledge (PK) and the types of errors that are made based on the Newman procedure. The research method used is descriptive qualitative case research. The subjects of this study were 50 level IV students taking Statistics on ELT (English Language Teaching) courses in the English Language Program at a university in Cirebon. The results of the data show that the ability of the prospective teacher's mathematical representation in solving statistical questions in ELT in terms of PK, namely the upper group with an average of $76.57 \%$ lower than the average midterm score of 95.75 , the middle group with an average $67.82 \%$ lower than the midterm average of 82 , and the lower group with an average of $38.33 \%$ lower than the midterm average of $57 \%$. The types of mistakes made by the SKB group were many mistakes in understanding the problem, transforming the problem, and the final answer. The SKS group had the most mistakes in the final answer and the SKA group had the most errors in understanding the problem. Based on the results of research for learning mathematics to prospective language teachers starting from basic concepts, not only memorizing but concepts, giving problems related to the ability of mathematical representation with lots of practice questions, especially in statistical tests.

Keywords: mathematical representation ability, Newman's procedure, teachers, mathematics, EFL

\section{INTRODUCTION}

Mathematics is a language represented by verbal and symbols (P. P. Waller \& Flood, 2016). Mathematical language is a universal language, meaning that it can be understood by anyone regardless of what language they use (Adoniou \& Qing, 2014). Mathematics as a queen and servants of other sciences such as physics, chemistry, economics, and biology (Al-Agili et al., 2012) can also help solve human problems. This can be seen from the use of mathematics in every activity, especially in solving problems that occur in everyday life (Mahanta \& Islam, 2012). In the world of education, mathematics is a compulsory subject from elementary to middle school levels. At the tertiary level, mathematics becomes a General Basic Course in study programs other than mathematics or mathematics education. One of the courses that involves mathematics in the English study program is statistics on English Language Teaching (ELT). The statistics on ELT course has a weight of 3 credits.

Language, Logic, Mathematics, and Statistics are components that are intertwined with one another in a scientific activity. Language is a communication tool, logic is a pattern of thinking, mathematics plays a role in deductive thinking patterns and statistics plays a role in inductive thinking patterns $(\mathrm{H}$.

Citation: Kurniati, U., Setiyani., \& Sagita, L. (2021). Error analysis using Newman procedures and the mathematical representation ability of pre service English teachers. Anatolian Journal of Education, 6(2), 135-156. https://doi.org/10.29333/aje.2021.6211a 
Suyitno, 2008). According to (Planas \& Schütte, 2018), the big challenge of mathematics education research in the field of language is integrating various knowledge from various sources to understand language, learning and mathematical thinking processes. Statistics on ELT studies the size of central tendency, the spread, as well as several statistical hypothesis tests. The purpose of this course is to assist English students in data processing, especially in scientific activities that involve quantitative research. Therefore, it is very important in equipping English study program students with quantitative literacy. A person is said to have quantitative literacy if he / she is able to read, write, has knowledge related to numbers, and can apply it in the context of everyday life (Rafianti et al., 2018). One indicator of quantitative literacy is the ability to represent (AAC \& U, 2009) which means the ability to transform relevant information into various mathematical forms (for example, equations, graphs, diagrams, tables, words) (Rafianti et al., 2018). Representation ability is one of the five standard processes that students need to have and master in learning mathematics (Martin, 2000). The inclusion of representation as a standard component of the process in the Principles and Standards for School Mathematics in addition to problem solving, reasoning, communication and connection skills is quite reasonable because to think mathematically and communicate mathematical ideas one needs to represent them in various forms of mathematical representations (Fadillah, 2011). Furthermore, mathematical representation ability need to be mastered well because mathematical information is often presented in the form of language and symbols (Thomas et al., 2015).

In fact, there are many obstacles faced by students in studying statistics on ELT. Based on the results of the interviews, most of the English students took the Language study program because they did not like maths lessons. This is due to students' perceptions that mathematics is confusing, difficult to understand story problems, many formulas to remember, and weak in arithmetic operations. The assumption that mathematics is difficult (Erdogan et al., 2014) will cause anxiety in learning, which in turn affects learning achievement (Al-Agili et al., 2012). The problem of understanding sentences in questions is also the most difficult problem faced by students (Verschaffel et al., 2020). In addition, it was also found that many students did not understand how to process data, they did not even understand the research outputs presented in the report. As a shortcut, finally students took advantage of illegal data processing services to process and analyze data without studying the process first (Putra et al., 2018). Therefore, this data processing business is very popular and the location is close to the campuses.

Based on the results of the Final Semester Examination for the Statistics on ELT course in the odd semester of 2018-2019, the average UAS score is 51.06 or is in the letter of quality C. According to (Planas \& Schütte, 2018), a big challenge for mathematics education research is related to the language field is to integrate a variety of knowledge from multiple sources to understand the language of mathematics, learning and thinking processes. The results of learning statistics on ELT that are not yet optimal cannot be continued, it is necessary to analyze the answers to questions from prospective English teachers. This evaluation is carried out in order to minimize the occurrence of the same error repetition. Mathematical errors of prospective teachers need attention, because if they are not resolved immediately, the errors will have a successive impact on the next math problem (Sumule et al., 2018). Therefore, this paper will discuss the types of errors made by prospective English teachers in answering Statistics on ELT according to Newman's procedures and find out what the profile or description of how the ability of prospective English teachers to represent mathematics looks like.

Several studies related to the mathematical representation ability profile that have been carried out include the representation ability profile of UMP (Muhammadiyah Purwokerto University) physics education students (Fatmaryanti \& Sarwanto, 2015), elementary school students in Sumedang Selatan District (Handayani \& Juanda, 2019), VIII grade students at SMPN 3 Kaliwadir Tulungagung on SPLDV material (Permatasari, 2020) and class X students at SMKN 1 Boyolangu Tulungangung (Hermawan, 2018). The novelty in this study is to look at the mathematical representation ability 
profile involving prospective English teachers. This research needs to be done so that lecturers know the description of mathematical representation abilities and hope that they can design mathematics learning that is suitable for the characteristics of language students. Therefore, one of the research objectives discussed in this paper is to describe the profile of the mathematical representation ability of English Education students at Swadaya Gunung Jati University Cirebon in the Statistics on ELT course.

Several studies related to student error analysis have also been carried out, including the analysis of Student Errors in Solving Linear Inequalities (Amir, 2015), Vector (Jana, 2018), analytic geometry of the material fields of lines and circles (Imswatama, 2016), logic problems (Romadiastri, 2012), and Kalkulus I (Rahmawati, 2017). Previous studies were conducted on prospective mathematics education teachers and PGSD. Research involving prospective English teachers has never been carried out. types of mathematical errors in prospective English teachers in the Statistics on ELT course.This is important to determine the learning design, be it the design of teaching materials, media, models, and others that can be used appropriately in order to minimize the mistakes made.

\section{Review of Literature}

\section{Mathematical representation ability}

There are two types of mathematical representations, namely internal and external. The relationship between the two types of representation can be seen in Figure 1.

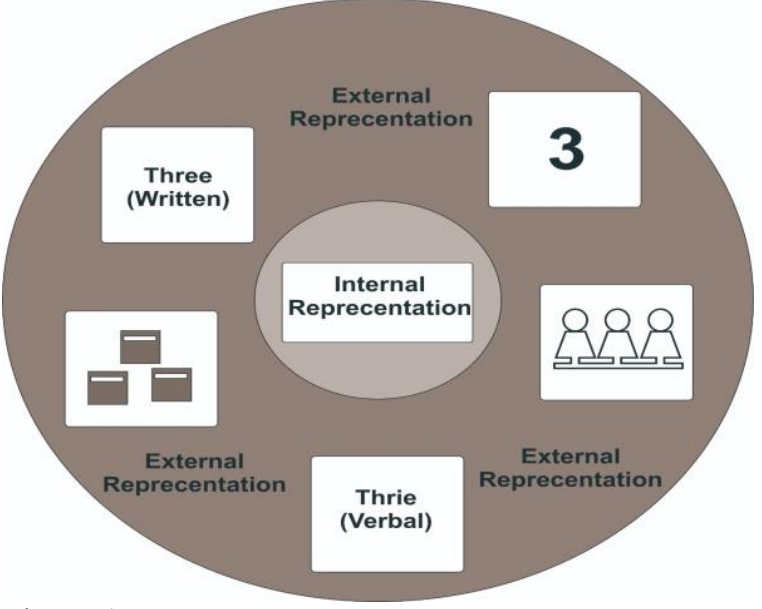

Figure 1

Mathematical representation in number 3

Figure 1 shows a process of mathematical representation ability in numbers. For example, when we say 3, students will represent 3 in their minds with something else such as numbers, writing, or pictures. The ability of representation arises from the process of the reciprocal relationship between internal and external representations. Internal representation ability is the ability possessed by students as activities in the mind that are invisible or non-visual, such as mathematical modeling and numerical representation (Minarni et al., 2016). While external representation is a form of internal representation of something that can be seen in the form of words, symbols, diagrams so that it can be expressed verbally and in writing (Widakdo, 2017). This is in line with (Yuanita et al., 2018), that there are 5 external levels of mathematical representation including objects in the real world, multiple representations, arithmetic symbol representations, verbal representations, and image or graphic representations. Statistics on ELT is a subject that can develop this mathematical representation 
ability. This is in line with Widodo and Aristyo who said that statistical problems, especially the Hypothesis Test material, have a variety of representations for solving problems (Aristiyo, 2019). Therefore, the ability of mathematical representation is a basic ability that students must have (Jitendra et al., 2016).

\section{Mathematical errors}

The problem is the gap between hope and reality. A math problem can become a math problem if the prospective teacher does not have a picture to solve the problem, but the teacher candidate wishes to solve the math problem (Widodo, 2013). Thus prospective teachers are said to make mistakes if they do the questions incorrectly. This can happen in the problem solving process or in the final result. When prospective teachers solve problems incorrectly, an in-depth analysis of the answers can help lecturers classify the types of mistakes that are mostly made and make plans to minimize errors (Nelson \& Powell, 2018). There are several types of errors in solving math problems. According to Sriati (Sulistyowati, 2015), students' mistakes in doing math problems include: 1. Errors in making mathematical modeling. 2. Concept errors, namely errors in understanding mathematical concepts. 3. Strategy errors, namely mistakes that occur because students choose the wrong way to do it. 4 . Systematic errors, namely errors relating to incorrect selection of extrapolation techniques. 5. Sign errors, namely errors in giving or writing mathematical signs or notations. 6. Calculation errors, namely errors in performing mathematical operations. The results of the research by (Adnyana \& Bennu, 2019) show the location of the students' math errors including conceptual and procedural errors. Conceptual errors that often occur include misunderstanding problems, applying principles or operating rules, etc. While procedural errors include one due to incomplete procedures, doing arbitrary, wrong in arithmetic operations. . In this paper, the mistakes made by prospective English teachers in solving Statistics on ELT questions. will be reviewed from the problem solving stage according to Newman, namely (1) error reading the question; (2) misunderstanding the problem; (3) transformation error; (4) errors in process skills; and (5) errors in writing answers.

\section{Newman's procedure}

The Newman error analysis method was first introduced in 1977 by Anne Newman, a mathematics teacher in Australia. The Newman procedure is often used to determine different types of student errors in doing math problems in many countries such as India, Malaysia, Thailand, Australia, and others (A. Suyitno \& Suyitno, 2015). The error category based on the problem solving process according to Newman (Wijaya et al., 2014) consists of 5 types, namely: reading errors, understanding, transformation, processing skills and writing errors in answers. The indicators for the five types of errors in the statistics on ELT course refer to Newman's error category and are described in the following table (Dirgantoro et al., 2019) :

Table 1

Newman's error category

\begin{tabular}{ll}
\hline Newman's Error Category & Error of Indicator \\
\hline Reading & - \\
\hline Understanding of the & - Not using proper statistical tests. \\
Problems & $-\quad$ Wrong in choosing and using data from \\
& Questions. \\
\hline Transformation & Wrong or not writing the research hypothesis. \\
\hline Process Skill & Using an incorrect formula \\
& $-\quad$ The formula used is correct but the process is not finished. \\
& $-\quad$ Wrong in determining criteria \\
\hline Written Answer Error & - acceptance / rejection of the hypothesis \\
\hline
\end{tabular}




\section{METHOD}

This research is qualitative research which aims to describe the mathematical representation ability profile in solving statistical problems. The research method used is descriptive qualitative. The sample in this study was all students of level III English Education study program in 2020 who took statistics on ELT as many as 50 students consisting of 9 boys and 41 girls. The research subjects were divided into three groups of mathematical abilities, namely high, medium and low level mathematical abilities which were obtained based on the students' initial mathematical ability/prior knowledge (PK) from the results of the even midterm exam, which amounted to 5 questions. The level of PK for each student is divided into three as in the following table :

Table 2

Research subject grouping based on prior knowledge (PK)

\begin{tabular}{ll}
\hline Criteria & Category \\
\hline $\mathrm{PK} \geq \mathrm{X}^{-}+\mathrm{s}$ & Upper Group \\
\hline $\mathrm{X}^{-} \mathrm{s}<\mathrm{PK}<\mathrm{X}^{-}+\mathrm{s}$ & Medium Group \\
\hline $\mathrm{X}^{-\mathrm{s}} \leq \mathrm{PK}$ & Lower Group \\
\hline
\end{tabular}

The instrument in this study was the researcher himself as the main instrument and a validated test of the thinking ability of mathematical representations. The indicators of the ability of mathematical representation in this study are :

Table 3

Mathematical representation ability indicators

\begin{tabular}{ll}
\hline Aspect of mathematical representation Ability & Indicators \\
\hline Visual Representation & Use visual representations to solve problems. \\
\hline Representation of mathematical Expressions & Create a mathematical equation or model from a given representation. \\
\hline Verbal Representation & Write an interpretation of a representation. \\
\hline
\end{tabular}

The steps in the research process are: 1 . Provide a preliminary mathematical ability test, 2 . Analyze and convert the test results based on PK into three categories, namely high, medium and low groups, 3 . Provide a Mathematical Representation Ability Test. The test is in the form of data processing questions, which are arranged based on indicators of mathematical representation ability. 4. Analyzing the mathematical representation ability of prospective English teachers in terms of PK, 5. Analyzing the types of errors of prospective English teachers based on Newman procedures, 6. Reducing, abstraction, transformation and categorization of data and triangulating sources to obtain valid data. 7 . Interpret and conclude research results. The table of categories of students' mathematical representation abilities can be seen in table 4. (Aryanti \& Nursangaji, 2013)

Table 4

Category of mathematical representation ability

\begin{tabular}{ll}
\hline Percentage & Category \\
\hline$\geq 90$ & Excellent \\
\hline $80 \%-89 \%$ & Good \\
\hline $65 \%-79 \%$ & Fair \\
\hline $55 \%-64 \%$ & Poor \\
\hline$<55 \%$ & Very Poor \\
\hline
\end{tabular}

\section{FINDINGS AND DISCUSSION}

This research was conducted in September - January 2020 at the Gunung Jati Swadaya University (UGJ) Cirebon with the research subjects being students of level III who contracted the Statistics On ELT (English Language Teaching) course. From the beginning of the semester to the midterm examinations, students study descriptive statistics. In this period, observations were made on the initial 
mathematical abilities of English Language Education students. Furthermore, the researcher used the mid semester results to group students based on prior knowledge. This is in line with Lestari and Yudhanegara who stated that another alternative in grouping students based on their initial mathematical ability level is to use data on daily test scores or last semester test scores (Lestari \& Yudhanegara, 2015). The period after midterm to Final Examination students learn topics in inferential statistics. Before final exam, students were asked to take a mathematical representation ability test to see the profile of mathematical representation abilities based on Prior Knowledge (PK). To perform data processing, SPSS software is used.

\section{Profile of Mathematical Representation Ability of Prospective English teachers}

Based on the test scores, it was found that the mathematical representation ability profile on the statistical hypothesis test material for level III students of English Education Study Program, Gunung Jati Cirebon University, was based on the PK value. Data on the mathematical representation ability of three groups of students with high, medium and low abilities are as follows:

Table 5

Representation Ability of Prospective English teachers

\begin{tabular}{llll}
\hline Indicators & \multicolumn{3}{l}{ Percentage of Pre service English Teachers } \\
\cline { 2 - 4 } & Low & Medium & High \\
\hline Use visual representations to solve problems. & $42 \%$ & $76.87 \%$ & $71.43 \%$ \\
\hline Create a mathematical equation or model from a given representation & $28 \%$ & $62.19 \%$ & $68.33 \%$ \\
\hline Write an interpretation of a representation & $45 \%$ & $64.4 \%$ & $90 \%$ \\
\hline Average & $38.33 \%$ & $67.82 \%$ & $76.57 \%$ \\
\hline
\end{tabular}

Furthermore, the data were analyzed in depth to obtain an overview of the students' mathematical representation abilities from the three groups. :

\section{Lower Mathematics Ability Subject (SKB)}

Use Visual Representations to Solve Problems.

Question 1. Construct a hypothesis from the SPSS output below.

One-Sample Test

\begin{tabular}{|c|c|c|c|c|c|}
\hline \multicolumn{6}{|c|}{ Test Value $=20$} \\
\hline \multirow[b]{2}{*}{$\mathrm{t}$} & \multirow[b]{2}{*}{ df } & \multirow{2}{*}{$\begin{array}{l}\text { Sig. (2- } \\
\text { tailed) }\end{array}$} & \multirow[b]{2}{*}{ Mean Difference } & \multicolumn{2}{|c|}{ 95\% Confidence Interval of the Difference } \\
\hline & & & & Lower & Upper \\
\hline 4.025 & 19 & .001 & 2.85000 & 1.3679 & 4.3321 \\
\hline
\end{tabular}

In accordance with the problems given, most of the SKB wrote test criteria to answer questions related to hypotheses from the visual representations presented (SPSS output).

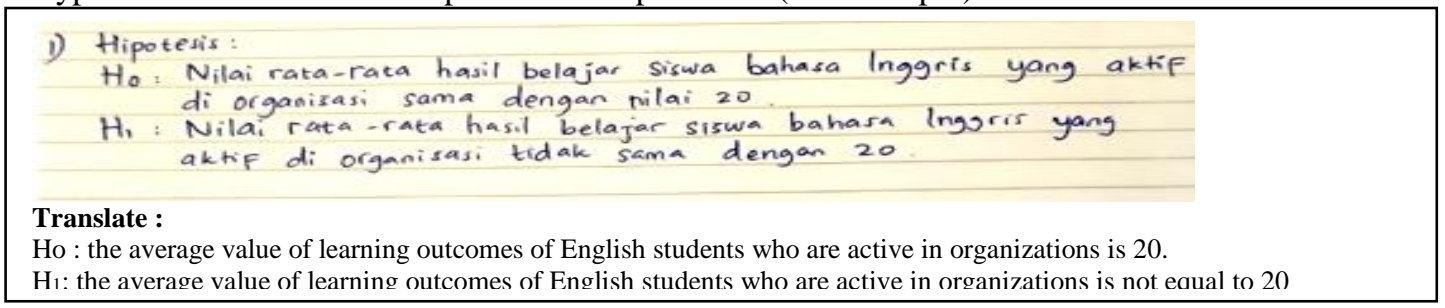

Figure 2

One of the SKB answers (Question No. 1)

Some SKB also do not understand the meaning of each number listed in the SPSS output. This is evidenced by an error in interpreting the numbers in the SPSS output. One of the SKB answers can be seen in figure 2. 
In Figure 2, SKB can make null and alternative hypotheses with their own language and according to the given SPSS output. In question number 1 for the SKB group, there were 3 students who answered correctly and 6 students answered but not correctly and 1 student did not answer.

\begin{tabular}{|c|c|c|c|c|c|c|}
\hline \multirow[b]{2}{*}{ Model } & & \multicolumn{2}{|c|}{$\begin{array}{c}\text { Unstandardized } \\
\text { Coefficients }\end{array}$} & \multirow{2}{*}{$\begin{array}{l}\text { Standardized Coefficients } \\
\text { Beta }\end{array}$} & \multirow[b]{2}{*}{$\mathrm{t}$} & \multirow[b]{2}{*}{ Sig. } \\
\hline & & $B$ & Std. Error & & & \\
\hline \multirow[t]{2}{*}{1} & (Constant) & 7.439 & 5.394 & & 1.379 & .176 \\
\hline & Student's activity & .939 & .076 & .894 & 12.304 & .000 \\
\hline
\end{tabular}

a. Dependent Variable: Posttest

Create a Mathematical Equation or Model from a Given Representation.

Question 2. Create a regression equation from the results of the SPSS output below:

\begin{tabular}{lcccc}
\hline \multicolumn{5}{c}{ Model Summary $^{\mathrm{b}}$} \\
\hline Model & $\mathrm{R}$ & \multicolumn{1}{c}{ R Square } & Adjusted R Square & \multicolumn{1}{c}{ Std. Error of the Estimate } \\
\hline 1 & $.894^{\mathrm{a}}$ & .799 & .794 & 4.65648 \\
\hline $\begin{array}{l}\text { a. Predictors: (Constant), Aktivitas Siswa } \\
\text { b. Dependent Variable: Posttest }\end{array}$ & & & \\
\hline
\end{tabular}

In accordance with the problems given, SKB has not been able to make a mathematical model from the SPSS output table representation. Most of the SKB solve the problem of creating a mathematical model by writing down the interpretation of the SPSS output and making a hypothesis. There are students who answer by calculating the correlation coefficient. Even though what is being asked in the question is to make a mathematical model. One of the answers of students in the SKB group that is considered to represent other students can be seen in figure 3 .

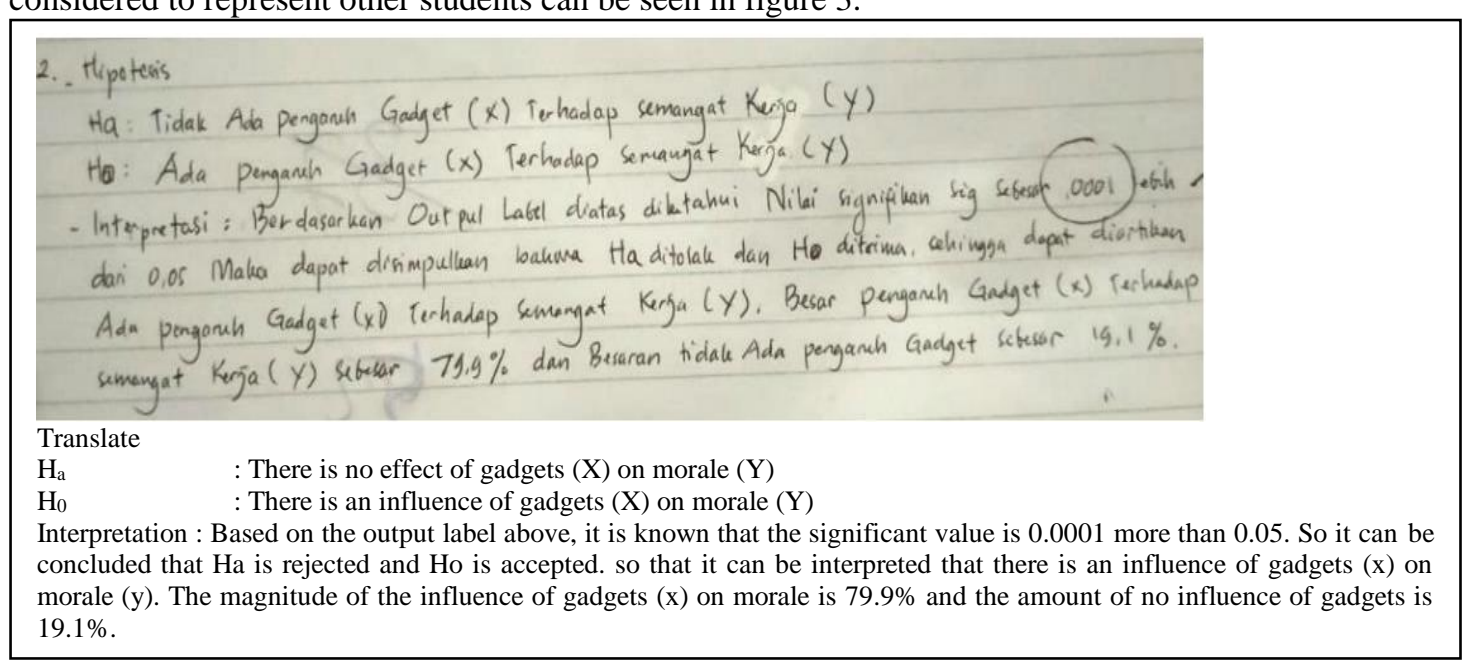

Figure 3

One of the SKB answers (Question No. 2)

In Figure 3, students calculate the influence of student activities on learning achievement. SKB group students were fooled by the two SPSS output tables given. In Problem No. 2 for the SKB group, there were 1 student who answered correctly and 9 incorrectly 
Write an Interpretation of a Representation.

Question 3. Provide an interpretation of the results of the SPSS output

\begin{tabular}{lllllll}
\hline & \multicolumn{4}{c}{ One-Sample Test } \\
\cline { 2 - 7 } & & \multicolumn{4}{c}{ Test Value $=20$} \\
\cline { 2 - 7 } score & & df & Sig. (2-tailed) & Mean Difference & \multicolumn{2}{l}{ 95\% Confidence Interval of the Difference } \\
\cline { 2 - 7 } & 4.025 & 19 & .001 & 2.85000 & 1.3679 & 4.3321 \\
\hline
\end{tabular}

In accordance with the problems given, most of the SKB answered interpretations with hypotheses. Students in the SKB are still unable to sort decimal values so they are still wrong in determining greater or lesser. One of the answers of students in the SKB group that is considered to represent other students can be seen in figure 4.

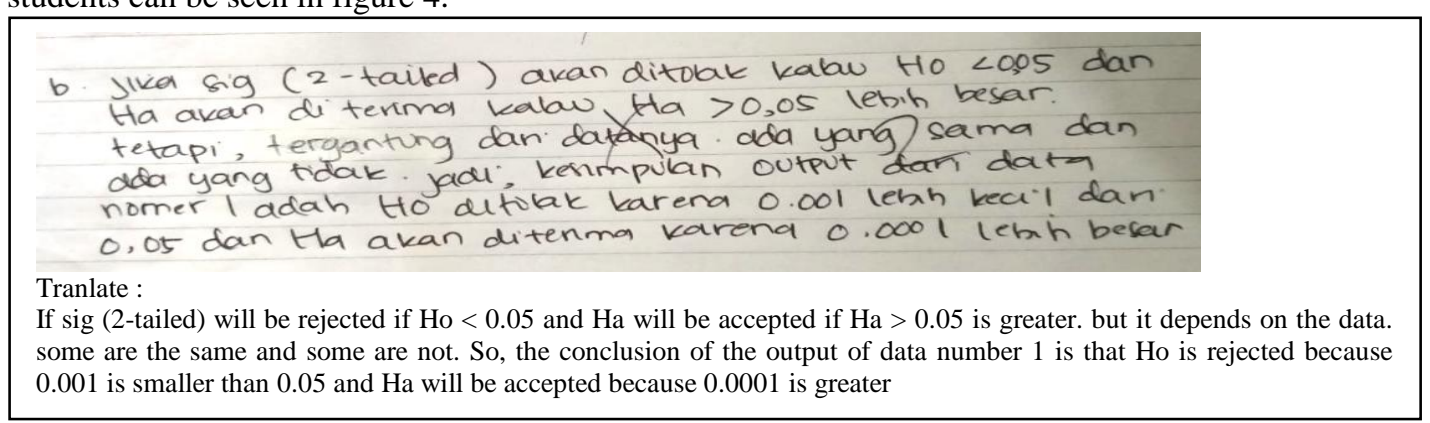

Figure 4

One of the SKB answers (Question No. 3)

In figure 4, students write Sig. 0.0001 is greater than 0.05 , so it is wrong in making interpretations. Students also still do not interpret the hypothesis testing criteria. In question No. 3 for the SKB group, there were 3 students who answered correctly, 6 answered but not correctly and 1 did not answer.

\section{Medium Mathematics Ability Subject (SKS)}

Use Visual Representations to Solve Problems.

In accordance with the problems given, most of the credits can make hypotheses from a given visual representation. Students can distinguish $\mathrm{H} 0, \mathrm{Ha}$ and interpret the answers to questions. However, there are also students in the SKS group who are still constrained in making hypotheses. One of the answers of students in the SKS group that is considered to represent other students can be seen in the following picture.

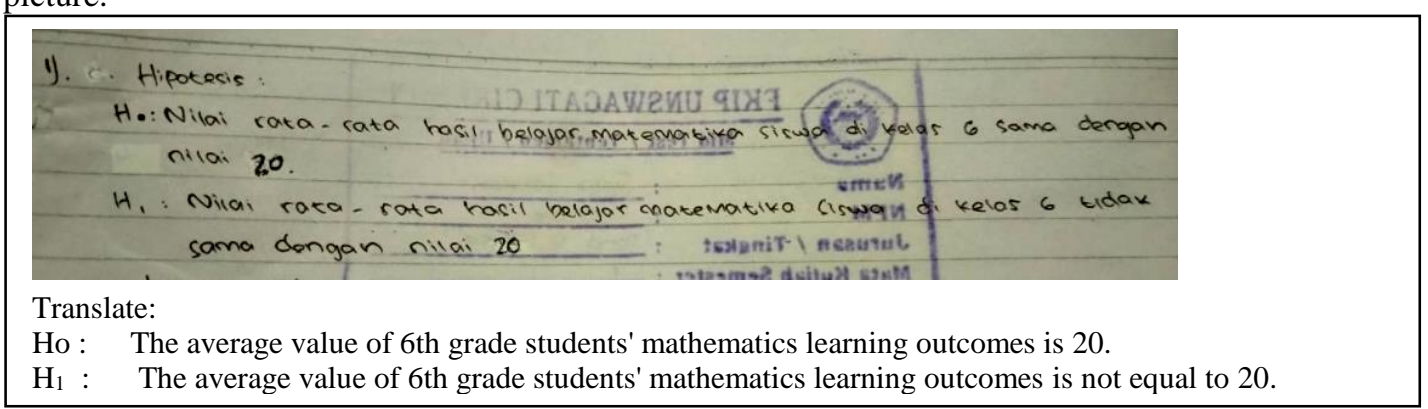

Figure 5

One of the SKS answers (Question No. 1)

Anatolian Journal of Education, October 2021 • Vol.6, No.2 
In Figure 5, students in the SKS group can already make null and alternative hypotheses in their own language according to the SPSS output. In question No. 1 for the SKS group, there were 24 students who answered correctly, and 8 answered but not correctly.

\section{Create a Mathematical Equation or Model from a Given Representation.}

In accordance with the problems given, most of the credits have been able to make regression equations from the given representations. Some students are still confused by the two outputs presented so that many make interpretations of the correlation coefficient. One of the answers of students in the SKS group which is considered to represent other students can be seen in figure 6 :

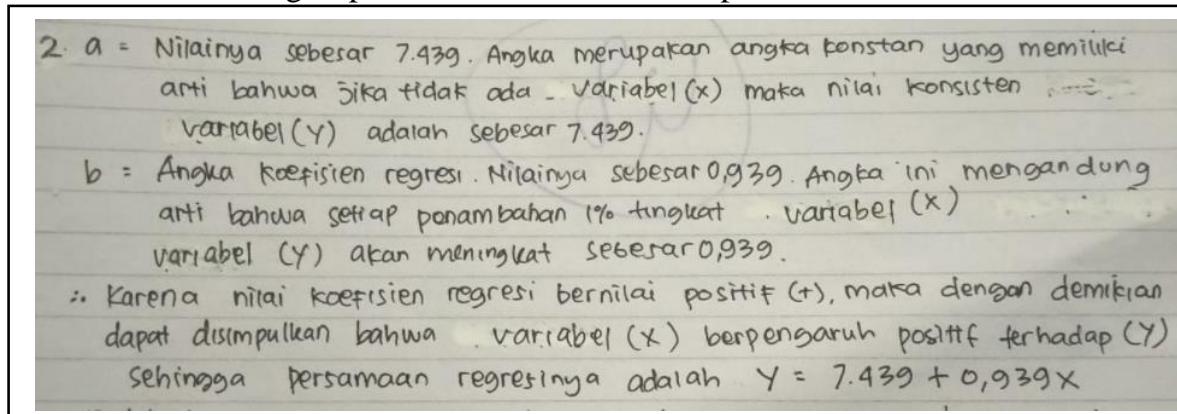

$\mathrm{a}=$ The value of 7.439 is a constant number which means that if there is no $\mathrm{x}$ variable then the constant value of the y variable is 7.439 .

$\mathrm{b}=$ regression coefficient number. The value is 0.939 . This figure means that for every $1 \%$ addition to the level of the variable $x$, the variable $y$ will increase by 0.939 .

so because the value of the regression coefficient $(+)$, it can be concluded that the variable (x) has a positive effect on $(\mathrm{y})$. so the regression equation is $\mathrm{Y}=7.439+0.939 \mathrm{x}$

Figure 6

One of the SKS answers (Question No. 2)

In Figure 6, students in the SKS group can make mathematical modeling appropriately and make interpretations. In question No. 2 for the SKS group, there were 16 students who answered correctly, 14 answered but did not answer correctly and 2 did not answer.

\section{Write an Interpretation of a Representation.}

In accordance with the problems given, most of the credits have been able to interpret the representation of the given SPSS output correctly. Students can distinguish between interpretations and hypotheses. However, some students are still constrained by the interpretation of the symbols $\mathrm{H}_{0}$ and $\mathrm{H}_{\mathrm{a}}$. One of the answers of students in the SKS group which is considered to represent other students can be seen in figure 7:

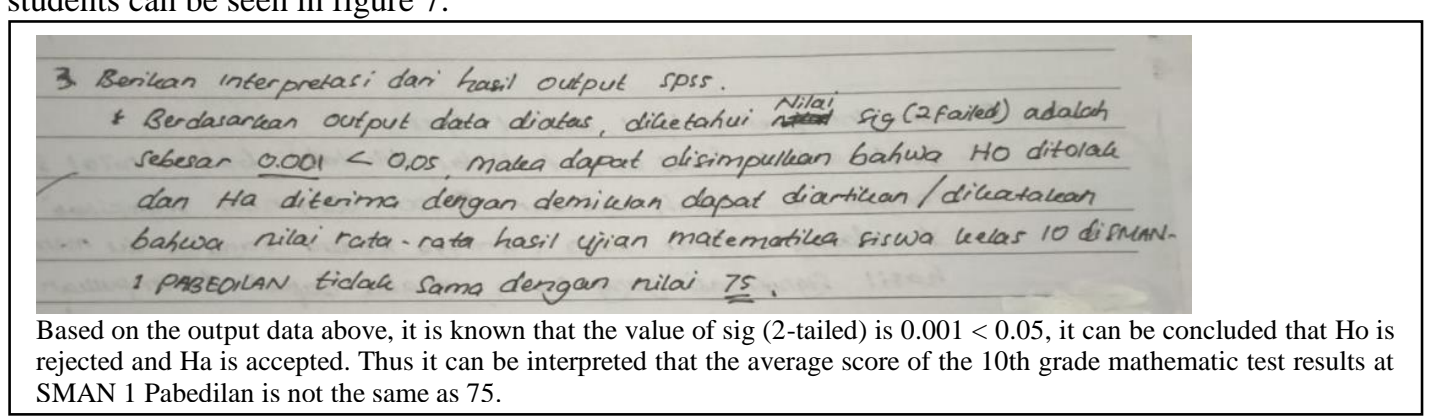

Figure 7

One of the SKS answers (Question No. 3)

Anatolian Journal of Education, October $2021 \bullet$ Vol.6, No.2 
In Figure 7, students in the SKS group can provide interpretations in their own language based on the representation given. Students already understand the test criteria, but they still have not provided an interpretation. $\mathrm{H}_{0}$ is rejected and $\mathrm{H}_{\mathrm{a}}$ is accepted. In question No. 3 for the SKS group, there were 17 students who answered correctly, 12 answered but did not answer correctly and 3 did not answer.

Upper Mathematics Ability Subject (SKA)

Use Visual Representations to Solve Problems.

In accordance with the problems given, most SKA can make hypotheses from the visual representations presented. However, some SKAs still write down the test criteria. This means that there are several SKA that still cannot differentiate between the hypothesis and the test criteria. One of the answers of students in the SKA group that is considered to represent other students can be seen in the following picture.

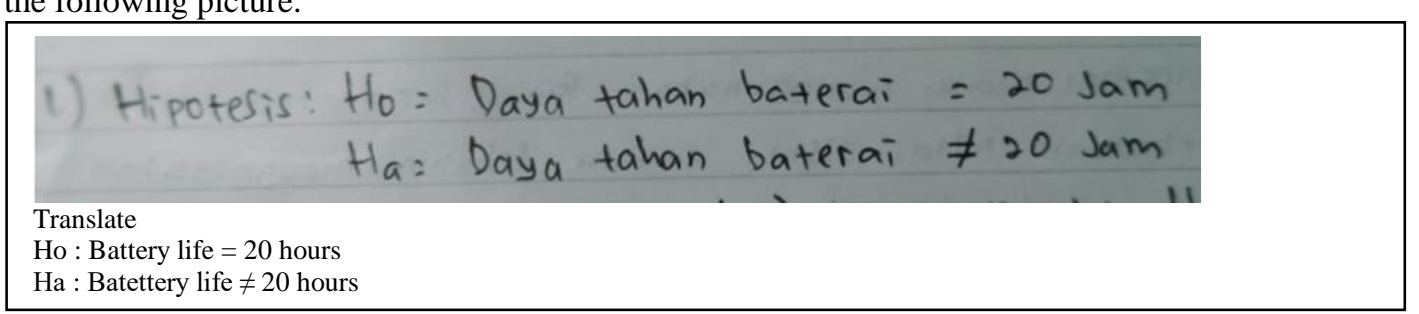

Figure 8

One of the SKA answers (Question No. 1)

In Figure 8, one of the SKA's can write a difference test hypothesis. $\mathrm{H}_{0}$ : Battery life $=20$ hours and $\mathrm{H}_{\mathrm{a}}$ : battery life $\neq 20$ hours. In question No. 1 for the SKA group, 4 students answered correctly and 4 students answered incorrectly.

Create a Mathematical Equation or Model from a Given Representation.

According to the given problem, most of the SKA can construct simple linear regression equations from the given representations. Students in the SKA group have been able to give the meaning of the regression equation correctly. Only a small proportion of SKA answered the coefficient of determination. One of the answers of students in the SKA group that is considered to represent other students can be seen in figure 9. 


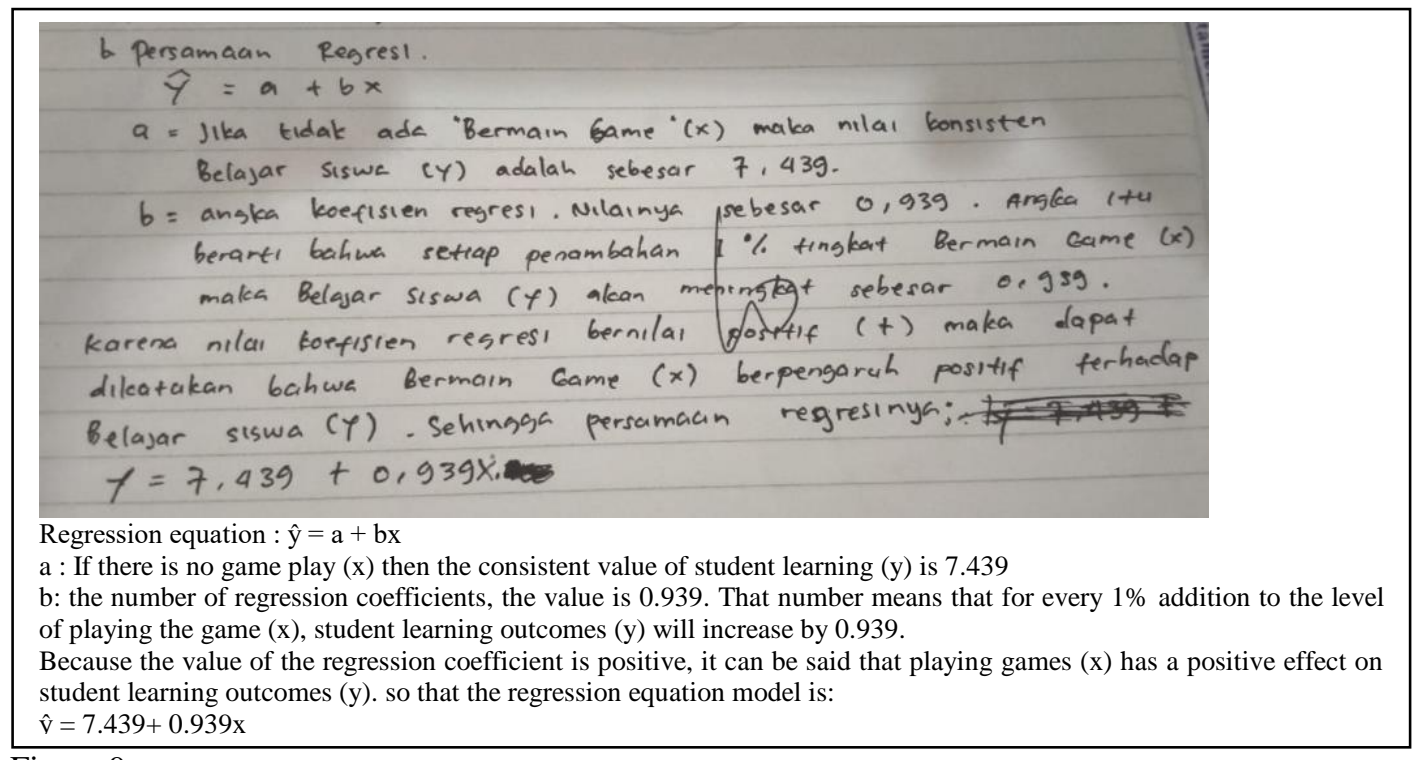

Figure 9

One of the SKA answers (Question No. 2)

In Figure 9, one of the SKA writes the general regression equation first, namely $\mathrm{Y}^{\wedge}=\mathrm{a}+\mathrm{bX}$ then writes the regression equation according to the given representation. SKA provides an interpretation of the answered regression equation. In question no. 2 for the SKA group, 3 students answered correctly and 5 students answered incorrectly.

\section{Write an Interpretation of a Representation.}

In accordance with the given problem, most of the SKA can make an interpretation from the given SPSS output table representation. Students in the SKA group write their interpretations by referring to the predetermined test criteria. A small proportion of SKA are still mistaken in making interpretations. For example, writing is not the same as being not less. This resulted in the value obtained was not optimal. One of the answers of students in the SKA group that is considered to represent other students can be seen in figure 10 .

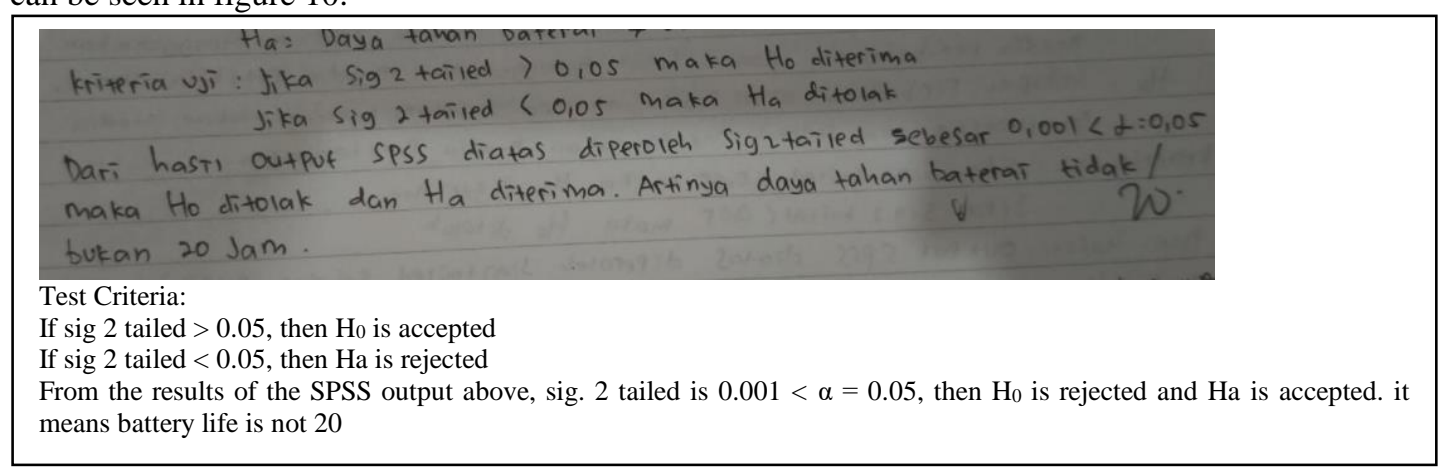

Figure 10

One of the SKA answers (Question No. 3) 
In Figure 10, one of the students' answers from the SKA group can provide an interpretation according to the representation given. Before giving interpretation, SKA wrote the test criteria first. In question No. 3 for SKA groups, 6 students answered correctly and 2 students answered but not correctly.

\section{Types of Errors Resolving Problems Based on Newman Procedures}

After getting an overview of the mathematical representation of prospective English teachers, the researchers then analyzed what types of errors were made in the SKB, SKS, and SKA groups based on the Newman Procedure. The following is a recapitulation table of the percentage of errors per question number.

Table 6

Types of Errors the Prospective English teachers

\begin{tabular}{llll}
\hline Error Type & \multicolumn{3}{l}{ Ability Level } \\
\cline { 2 - 4 } & SKA & SKS & SKB \\
\hline Reading & - & - & - \\
\hline Understanding the Problem & $50 \%$ & $25 \%$ & $60 \%$ \\
\hline Transformation & $37.5 \%$ & $37.5 \%$ & $60 \%$ \\
\hline Process Skills & $25 \%$ & $9.4 \%$ & $30 \%$ \\
\hline Written Answer Error & $25 \%$ & $34.38 \%$ & $60 \%$ \\
\hline
\end{tabular}

Misunderstanding the Problem in SKA, SKS, SKB.

Mistakes in understanding the problem mostly occur in the second indicator, namely misunderstanding and using the problem. This error can be seen in Figure 11. 


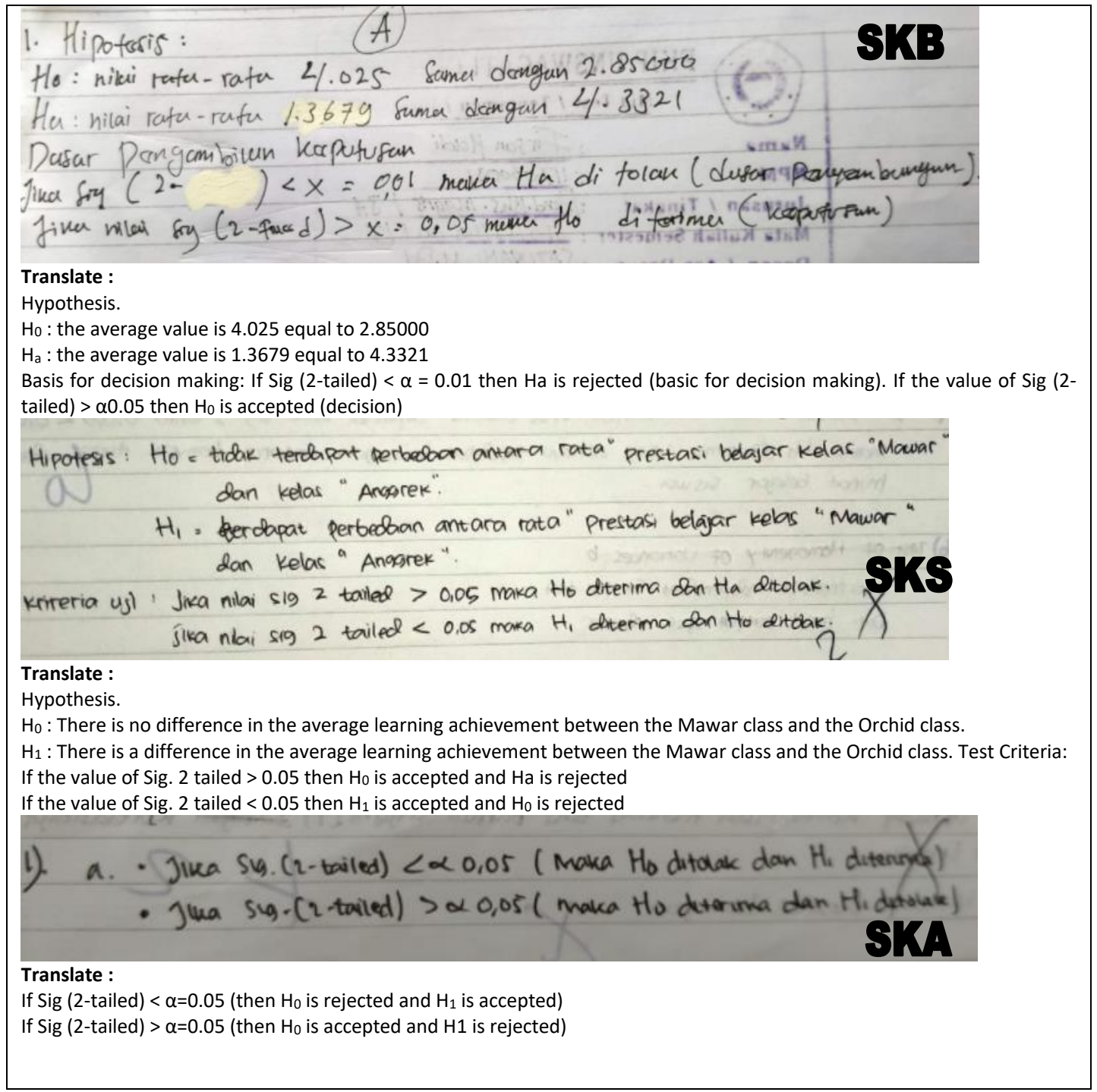

Figure 11

Examples of SKB, SKS, and SKA answers

In Figure 11, for the SKB group, it can be seen that prospective English teachers have not yet understood the meaning of each number listed in the SPSS output. This is evidenced by an error in interpreting the figures in the SPSS outputs. SKB wrote 4.025 and 1.3679 as the average value which should be the count and the lowest value at the $95 \%$ significance level. Misunderstanding other problems for the SKB group include SKB writing the data normality hypothesis even though the desired hypothesis is the difference of one sample. In addition, SKB did not write down the null hypothesis and its counter hypothesis exactly according to the SPSS output. The SKB defines the test criteria and interpretation of the results even though what is requested is a hypothesis.

In figure 11, one of the English teacher candidates in the SKS group made a wrong hypothesis. SKS writes the two-sample difference test hypothesis which should be one-sample difference test. In Figure 
10 the SKA group, part of the mistakes of the prospective English teachers lies in making a hypothesis because they do not understand the SPSS output well. The answer that is asked is to make a research hypothesis but SKA writes the test criteria.

\section{Transformation Error}

Transformation errors mostly occur in indicators using incorrect formulas. SKB, SKS, and SKA group errors can be seen in Figure 12.

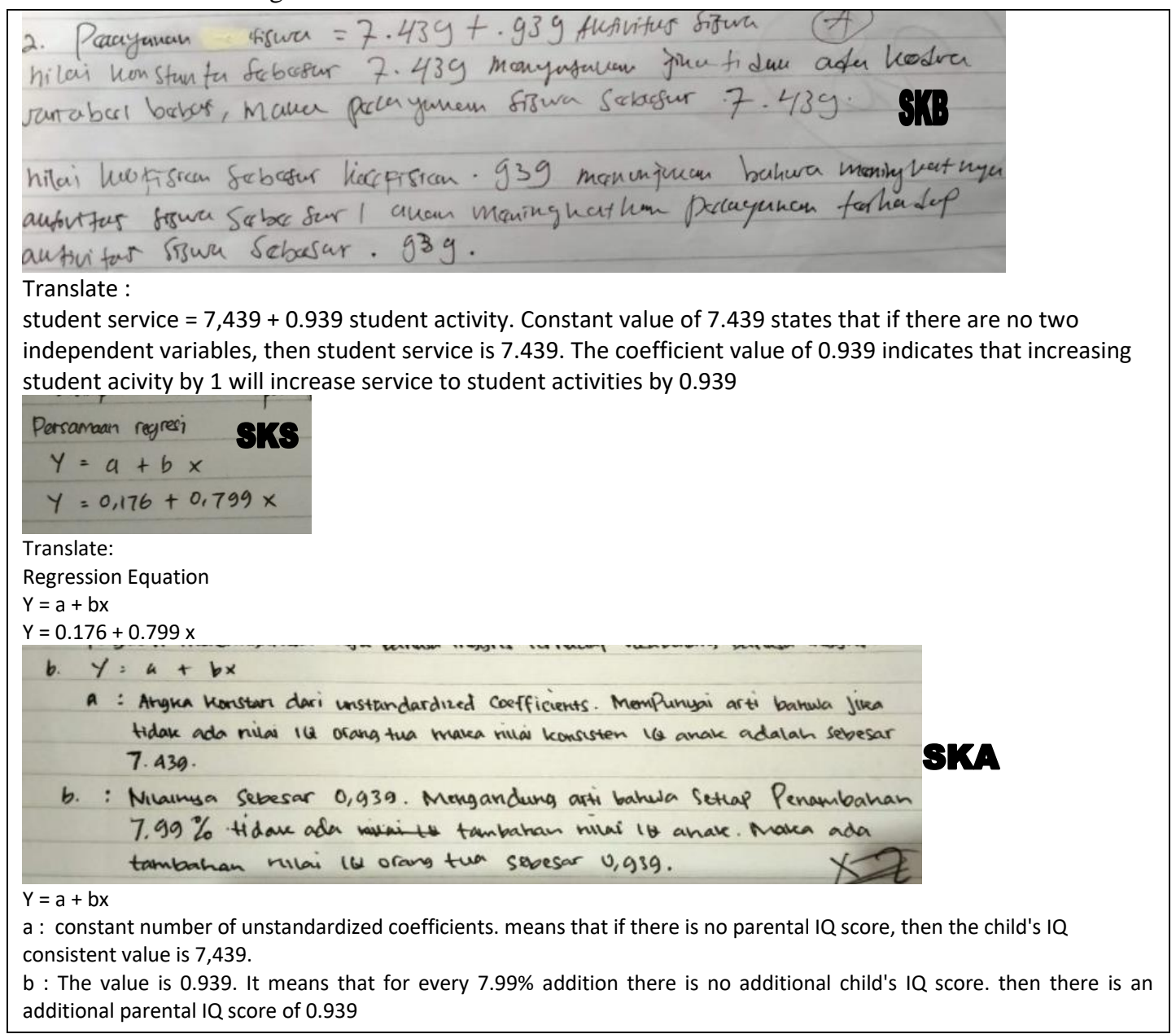

Figure 12

Examples of SKB, SKS, and SKA answers

In Figure 12, for the SKB group, the fault lies in the transformation of the mathematical symbol. SKB has not transformed student services into a symbol $\widehat{Y}$ and student activities into $X$. In addition, the formula that has been written is not the same as the meaning given. In the regression formula, SKB writes the dependent variable of student activity, while in the interpretation it writes student services. It is suspected, SKB still cannot distinguish the dependent variable and the independent variable. Furthermore, based on one of the SKS group answers, the general equation written down is correct. However, SKS was wrong in writing the constants. SKS says 0.176 should be 7,349 . In addition, other 
SKS errors are incorrectly used formulas, incomplete in writing interpretations and writing hypothesis tests, interpretations, regression coefficients even though what is required is a regression equation. In the SKA group, the error lies in the use of incorrect formulas. SKA states the value of a as the regression coefficient (size of influence) which should be the coefficient of the independent variable.

\section{Process Skills Error}

Many processing skills errors occur in the error indicators in the correct formulas used but the work has not been completed. SKB, SKS, and SKA group errors can be seen in Figure 13

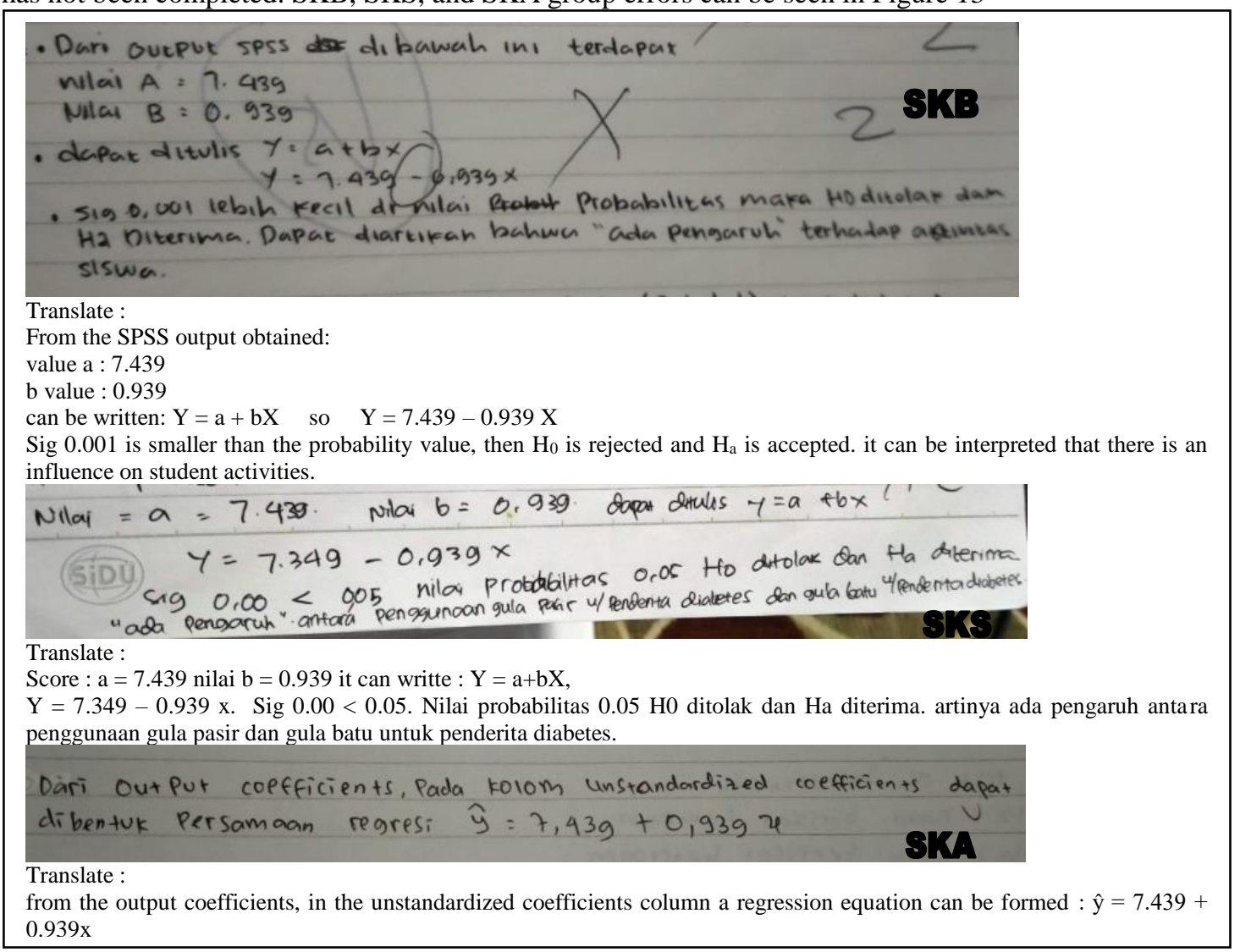

Figure 13

Examples of SKB, SKS, and SKA answers

In figure 13, the SKB group could not carry out the procedure correctly even though they had written the formula correctly. SKB has written the regression equation $\hat{y}=a+b x$ but it is wrong in interpreting the answer. SKB writes $\hat{y}=7.439-0.939 x$ which should be $\hat{y}=7.439+0.939 x$. In addition, SKB also experienced difficulties in giving meaning to the regression equation. This can be seen from the explanation regarding the linear regression equation. The SKB explains whether there is an effect or not, whereas the SKB should describe a regression model involving independent and bound variables. Similar to the SKB group, the SKS group also wrote down the regression equation correctly. However, the procedure is still wrong. SKS does not carefully read the constant value in the SPSS output and misrepresents the simple linear regression equation. In the SKA group, several SKAs were able to 
write the general regression equation and substitute it based on the SPSS output. However, this work should be equipped with an explanation of the meaning of the regression equation.

\section{Errors in Writing the Final Answer}

The error in writing the final answer occurred because students could not write the interpretation correctly and did not write a conclusion whether the null hypothesis was accepted or not. SKB, SKS, and SKA group errors can be seen in Figure 14.

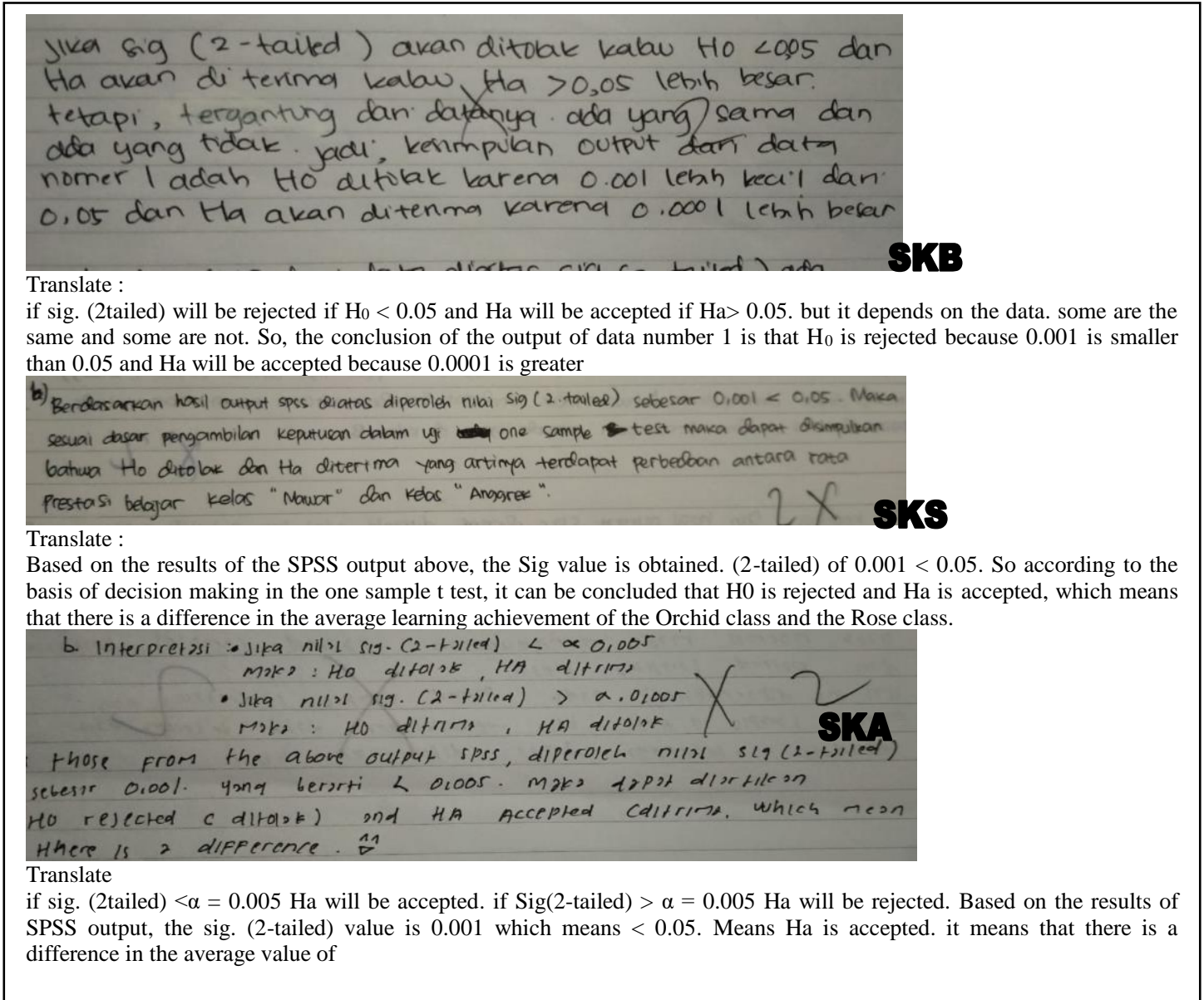

Figure 14

Examples of SKB, SKS, and SKA answers

In figure 14, one of the answers representing the SKB group regarding the error in writing the answers in Figure 14 is that the SKB does not provide a complete conclusion on the meaning of acceptance or rejection of $\mathrm{H}_{0}$. In the SKS group, the error lies in determining the statistical test. The output presented is related to the one-sample hypothesis test, but there are students who test the difference between two independent samples. The SKA group wrote down the test criteria before making interpretations. The fault lies with SKA not writing conclusions correctly. It is suspected that SKA is still confused about writing interpretations. To improve the quality of data observations on the results of SPSS output, complete observations are needed (J. A. Waller et al., 2016). 


\section{DISCUSSION}

Student ability is the most important factor in learning mathematics because it determines success in implementing learning and absorbing learning material (Tambunan, 2018). Effective mathematical problem solving begins with the problem representation phase (Krawec, 2014). Based on the above analysis, the ability of the three groups of students to represent the three groups of students in solving statistical questions on ELT is different. The most basic problem related to mathematical representation is the understanding of questions (Sajadi et al., 2013). In question Number 1, almost all SKB groups were still unable to make a hypothesis from the visual representation provided. Most of them make test criteria or other hypotheses that do not match the visual representation given. Even though what is desired in the questions is the one-sample comparison hypothesis according to the given SPSS output table. In the SKS and SKA groups, subjects had very little difficulty in making hypotheses. Subjects can make hypotheses based on their own sentences and adjusted to the given table representation. This is because during the learning statistics on ELT SKA and SKS are active in answering practice questions, presentations and group discussions.

In question number 2 with indicators of making mathematical equations or models from the given representation, the SKB group cannot make a simple linear regression model according to the output of SPSS. Almost all SKB did not write down the general equation for regression, misread the table, and were fooled by the determination coefficient table. In making a modeling or mathematical equation, the subject must be able to think abstraction. SKB does not have a good level of abstraction thinking. Even though the structure of mathematical representations can be seen in mental constructions / abstractions made to achieve and understand mathematical concepts (Widada \& Herawaty, 2017). The SKS and SKA groups have a good abstraction concept. In the SKS and SKA groups, subjects had very few difficulties in making mathematical equations or models. Subjects are able to recognize the relationship of a mathematical procedure of a representation to other equivalent representation procedures, and explain the mathematical model in their own language.

In question number 3 , with the indicator writing an interpretation of a representation, the SKB group was still wrong in ordering the decimal. This is a basic mathematical concept that the SKB group has not mastered well. In the SKS group, the interpretation given was still incomplete. Subjects are still confused about defining $\mathrm{H}_{0}$ as rejected or accepted. Therefore, both SKB and SKS must be reminded again of the basic concept of numbers and the meaning of each number in the SPSS output. This is in line with (Sundayana, 2012) that one of the weaknesses of students in statistics courses is that most of them are only able to perform calculations mechanically but students are still confused about interpreting and explaining the results of these calculations. This is important so that SKB and SKS can provide interpretations according to the representation given. In the SKA group, the subject had almost no difficulty in providing interpretation. This is evidenced by the three indicators of representation ability, writing an interpretation of a mathematical representation gets the highest score. Subjects can use mathematics in everyday life, understand the relationship between mathematical topics and provide interpretations according to representations. In general, the ability of mathematical representation is an important ability that needs to be developed for prospective English teachers. One way to improve mathematical representation skills is to provide an understanding of the language of mathematics. According to Verschafel, several steps to provide solutions to word problems include providing an understanding of the definition and developing a situation model, developing a mathematical model based on the right situation, working on mathematical models to obtain mathematical results, interpreting the results related to the problem situation, checking whether the interpreted mathematical results are appropriate (Verschaffel et al., 2020), with the goal and communicating the solutions obtained (Pongsakdi et al., 2020). Based on the problem of mathematical representation ability, it can be seen the types of errors that are often made by research subjects in terms of the Newman procedure. 


\section{Error Analysis of Prospective English Teachers in Making Research Hypotheses}

The material determines the hypothesis according to the representation contained in the type of question number 1 . Subjects are asked to make a one-sample difference test hypothesis with the provisions of Test Value $=20$. In making a hypothesis the subject is given the freedom to determine his own sentence as long as the null hypothesis and the match are right. An example of a null and counter hypothesis that can be made is :

$\mathrm{H}_{0}$ : $\quad$ (The average value of speech language proficiency in the control class =

$\begin{array}{ll}\mu_{0} \neq 20 & 20) \\ & \text { (The average value of speech impaired language proficiency in the } \\ & \text { control class is not 20). }\end{array}$

The most common mistake in question Number 1 is understanding the problem. Some of the errors found were misunderstanding the numbers in the SPSS output table, writing down the test criteria even though what was being asked was the hypothesis, wrong in determining the statistical test hypothesis, unable to determine the null and its counter hypothesis correctly. Errors in formulating hypotheses are caused because the subject does not understand the problem presented by the problem. This is in line with Putro's research which states that the causes of student errors in making hypotheses are caused by not being careful in understanding the problem and not understanding using connecting signs / notations (Putro \& Darminto, 2015).

Error Analysis of Prospective English Teachers on Simple Linear Regression Equations.

The material for making a simple linear regression model is found in question number 2. Subjects are asked to write a simple linear regression model and explain its meaning. The general simple regression

equation is $\hat{y}=a+b x$, where $\hat{y}$ is the dependent variable and $x$ is the independent variable. Based on the questions obtained y diperoleh $\hat{y}=7.349+0,939 x$, meaning that if the value of listening ability increases by 1 , then the value of student activity will increase by 0.939 (a case example). The most common mistake found in the SKA, SKS and SKB groups was transformation. Some of these errors are, for example, the formula that has been written is not the same as the meaning given, still unable to distinguish the dependent variable and the independent variable, incorrectly writing constants and using incorrect formulas. In question number 2, there is a type of process skills error. This error occurs because you cannot run the procedure correctly even though you have written the formula correctly.

For example, SKB has written the regression equation $\hat{y}=a+b x$, but it misrepresents the answer.

SKB writes $\hat{y}=7.439-0.939 x$ which should be $\hat{y}=7.439+0.939 x$. Other errors include the subject having difficulty in giving the meaning of the regression equation, not being careful in reading the constant value in the SPSS output.

Error Analysis of Prospective English Teachers in Providing Interpretations.

The material providing interpretations is in question number 3 . The error in writing the final answer occurs because students cannot write the interpretation correctly. Interpretation can be developed by the subject in his own sentence as long as the meaning is in accordance with the SPSS output in the problem. For example, according to the representation given, the required test criterion is if the value of Sig.(2-tailed) $>\propto$, then $\mathrm{H}_{0}$ is accepted. Because Sig.(2-tailed) $=0.001<\propto=0.05$ then $\mathrm{H}_{0}$ is rejected, meaning that the average value of speech impaired language proficiency in the control class 
is not 20. Some of the mistakes of research subjects in giving interpretations include not giving complete conclusions about the meaning of acceptance or rejection of $\mathrm{H}_{0}$, not writing conclusions correctly. It is suspected that the research subjects are still confused about writing interpretations.

\section{CONCLUSION}

Based on the analysis and discussion and referring to the formulation of the problem, the following conclusions can be drawn: first, the ability of mathematical representation at the upper level is in the medium category, the medium level is in the medium category, and the lower level is in the very low category. Second, the SKB group made many mistakes in understanding the problem, transforming the problem, and writing the final answer. The SKS group made the most mistakes in writing the final answer and the SKA group made the most mistakes in understanding the problem. Based on the results of the research, the researcher suggests that learning should start from basic concepts, not only memorizing but understanding the concept of a material, giving problems related to mathematical representation abilities with lots of practice questions, especially in statistical hypothesis testing. This is important so that prospective English teachers can improve their quantitative literacy skills and conduct research with appropriate data processing.

\section{ACKNOWLEDGMENT}

Thanks to Universitas Swadaya Gunung Jati for providing research funding and for being trustworthy partners so that this research can be completed well.

\section{REFERENCES}

A. A. C. \& U. (2009). Quantitative literacy value rubric. [Online]. Tersedia: http://www.aacu.org/value/rubrics/pdf/QuantitativeLiteracy.pdf. [10 Agustus 2020].

Adnyana, I. W. P. G., \& Bennu, S. (2019). Analisis kesalahan siswa dalam menyelesaikan soal cerita operasi hitung pecahan di kelas vii smp negeri 18 palu. Jurnal Elektronik Pendidikan Matematika Tadulako, 6(4), 493-506.

Adoniou, M., \& Qing, Y. (2014). Language, mathematics and English language learners. Australian Mathematics Teacher, 70(3), 3-13.

Al-Agili, M. Z. G., Mamat, M. Bin, Abdullah, L., \& Maad, H. A. (2012). The factors influence students' achievement in mathematics: A case for Libyan's students. World Applied Sciences Journal, 17(9), 1224-1230.

Amir, M. F. (2015). Analisis kesalahan mahasiswa pgsd universitas muhammadiyah sidoarjo dalam menyelesaikan soal pertidaksamaan linier. Jurnal Edukasi, 1(2), 455-2443.

Aristiyo, D. N. (2019). Kemampuan representasi matematis mahasiswa dalam menyelesaikan masalah statistika berdasarkan langkah krulik dan rudnick. Jurnal Edukasi Dan Sains Matematika (JES-MAT), 5(2), 99-112.

Aryanti, D., \& Nursangaji, A. (2013). Kemampuan representasi matematis menurut tingkat kemampuan siswa pada materi segi empat di SMP. Jurnal Pendidikan Dan Pembelajaran Khatulistiwa, 2(1).

Dirgantoro, K. P. S., Saragih, M. J., \& Listiani, T. (2019). Analisis kesalahan mahasiswa PGSD dalam menyelesaikan soal statistika penelitian pendidikan ditinjau dari prosedur Newman [an analysis of primary teacher Education students solving problems in statistics for Educational research using the Newman procedure]. JOHME: Journal of Holistic Mathematics Education, 2(2), 83-96.

Erdogan, A., Yazlik, D. O., \& Erdik, C. (2014). Mathematics teacher candidates' metaphors about the 
concept of "mathematics." International Journal of Education in Mathematics, Science and Technology, 2(4), 289-299.

Fadillah, S. (2011). Meningkatkan Kemampuan Representasi Multipel Matematika Siswa SMP Melalui Pembelajaran Dengan Pendekatan Open Ended. Jurnal Pendidikan Matematika, 2(2), 100107.

Fatmaryanti, S. D., \& Sarwanto, S. (2015). Profil kemampuan representasi mahasiswa pendidikan fisika universitas muhammadiyah purworejo. Jurnal Pendidikan Fisika Dan Keilmuan (JPFK), 1(1), 20-22.

Handayani, H., \& JUANDA, R. (2019). Profil kemampuan representasi matematis siswa sekolah dasar di kecamatan sumedang selatan. Prosiding Sesiomadika, l(1a).

Hermawan, A. A. D. I. (2018). Profil kemampuan representasi matematis peserta didik kelas $x$ di smkn 1 boyolangu tulungagung.

Jana, P. (2018). Analisis kesalahan mahasiswa dalam menyelesaikan soal matematika pada pokok bahasan vektor. Jurnal Mercumatika: Jurnal Penelitian Matematika Dan Pendidikan Matematika, 2(2), 8-14.

Jitendra, A. K., Nelson, G., Pulles, S. M., Kiss, A. J., \& Houseworth, J. (2016). Is mathematical representation of problems an evidence-based strategy for students with mathematics difficulties? Exceptional Children, 83(1), 8-25.

Krawec, J. L. (2014). Problem representation and mathematical problem solving of students of varying math ability. Journal of Learning Disabilities, 47(2), 103-115.

Lestari, K. E., \& Yudhanegara, M. R. (2015). Penelitian pendidikan matematika. Bandung: PT Refika Aditama, 2(3).

Mahanta, S., \& Islam, M. (2012). Attitude of secondary students towards mathematics and its relationship to achievement in mathematics. International Journal of Computer Technology and Applications, 3(2), 713-715.

Martin, W. G. (2000). Principles and standards for school mathematics (Vol. 1). National Council of Teachers of.

Minarni, A., Napitupulu, E. E., \& Husein, R. (2016). Mathematical understanding and representation ability of public junior high school in North Sumatra. Journal on Mathematics Education, 7(1), 4356. https://doi.org/10.22342/jme.7.1.2816.43-56

Nelson, G., \& Powell, S. R. (2018). Computation error analysis: Students with mathematics difficulty compared to typically achieving students. Assessment for Effective Intervention, 43(3), 144-156.

Permatasari, N. V. (2020). Profil kemampuan representasi matematis siswa kelas viii c di smpn 3 kalidawir tulungagung pada materi spldv tahun ajaran 2019/2010.

Planas, N., \& Schütte, M. (2018). Research frameworks for the study of language in mathematics education. $Z D M$, 5O(6), 965-974.

Pongsakdi, N., Kajamies, A., Veermans, K., Lertola, K., Vauras, M., \& Lehtinen, E. (2020). What makes mathematical word problem solving challenging? Exploring the roles of word problem characteristics, text comprehension, and arithmetic skills. ZDM, 52(1), 33-44.

Putra, Z., Hasan, I., Budianto, B., Maulidasari, C. D., \& Chan, S. (2018). Pelatihan pengolahan data penelitian dengan software spss bagi mahasiswa lintas perguruan tinggi dalam kabupaten aceh barat 
provinsi aceh. Abdimas: Jurnal Pengabdian Masyarakat Universitas Merdeka Malang, 3.

Putro, E. P., \& Darminto, B. P. (2015). Analisis kesalahan dalam menyelesaikan soal ujian akhir semester statistika dasar pada mahasiswa program studi pendidikan matematika. Ekuivalen, 18(1), 6368 .

Rafianti, I., Setiani, Y., \& Novaliyosi, N. (2018). Profil kemampuan literasi kuantitatif calon guru matematika. JPPM (Jurnal Penelitian Dan Pembelajaran Matematika), 11(1).

Rahmawati, A. (2017). Analisis kesalahan mahasiswa pendidikan matematika dalam menyelesaikan soal pertidaksamaan pada mata kuliah Kalkulus I. Al-Jabar: Jurnal Pendidikan Matematika, 8(1), 8190.

Romadiastri, Y. (2012). Analisis kesalahan mahasiswa matematika dalam menyelesaikan soal-soal logika. Jurnal Phenomenon, 2(1), 75-93.

Sajadi, M., Amiripour, P., \& Rostamy-Malkhalifeh, M. (2013). The examining mathematical word problems solving ability under efficient representation aspect. Mathematics Education Trends and Research, 2013, 1-11.

Sulistyowati, E. (2015). Error Analysis Geometry Questions on Working Class V SD/Mi in YOGYAKARTA. Jurnal Pendidikan Sekolah Dasar Ahmad Dahlan, 1(2), 71618.

Sumule, U., Amin, S. M., \& Fuad, Y. (2018). Error analysis of Indonesian junior high school student in solving space and shape content PISA problem using Newman procedure. Journal of Physics: Conference Series, 947(1), 12053.

Sundayana, R. (2012). Upaya meningkatkan kemampuan komunikasi statistika melalui pemberian praktikum pengolahan data berbantuan komputer pada mahasiswa prodi pendidikan matematika STKIP Garut. Mosharafa: Jurnal Pendidikan Matematika, 1(2), 51-58.

Suyitno, A., \& Suyitno, H. (2015). Learning therapy for students in mathematics communication correctly based-on application of newman procedure (a case of indonesian student). International Journal of Education and Research, 3(1), 529-538.

Suyitno, H. (2008). Hubungan antara bahasa dengan logika dan matematika menurut pemikiran Wittgenstein. Humaniora, 20(1), 26-37.

Tambunan, H. (2018). Impact of heuristic strategy on students' mathematics ability in high order thinking. International Electronic Journal of Mathematics Education, 13(3), 321-328.

Thomas, C. N., Van Garderen, D., Scheuermann, A., \& Lee, E. J. (2015). Applying a universal design for learning framework to mediate the language demands of mathematics. Reading \& Writing Quarterly, 31(3), 207-234.

Verschaffel, L., Schukajlow, S., Star, J., \& Van Dooren, W. (2020). Word problems in mathematics education: A survey. ZDM, 52(1), 1-16.

Waller, J. A., Dance, S. L., \& Nichols, N. K. (2016). Theoretical insight into diagnosing observation error correlations using observation-minus-background and observation-minus-analysis statistics. Quarterly Journal of the Royal Meteorological Society, 142(694), 418-431.

Waller, P. P., \& Flood, C. T. (2016). Mathematics as a universal language: transcending cultural lines. Journal for Multicultural Education.

Widada, W., \& Herawaty, D. (2017). The effects of the extended triad model and cognitive style on the abilities of mathematical representation and proving of theorem. 
Widakdo, W. A. (2017). Mathematical representation ability by using project based learning on the topic of statistics. Journal of Physics: Conference Series, 895(1), 12055.

Widodo, S. A. (2013). Analisis kesalahan dalam pemecahan masalah divergensi tipe membuktikan pada mahasiswa matematika. Jurnal Pendidikan Dan Pengajaran, 46(2 Juli).

Wijaya, A., van den Heuvel-Panhuizen, M., Doorman, M., \& Robitzsch, A. (2014). Difficulties in solving context-based PISA mathematics tasks: An analysis of students' errors. The Mathematics Enthusiast, 11(3), 555-584.

Yuanita, P., Zulnaidi, H., \& Zakaria, E. (2018). The effectiveness of Realistic Mathematics Education approach: The role of mathematical representation as mediator between mathematical belief and problem solving. PloS One, 13(9), e0204847. 